\title{
Oil Consumption and Economic Growth in Nigeria: A Multivariate Cointegration Analysis
}

\author{
Alexander Abraham Anfofum, Olure-Bank Adeyinka Michael, Oyefabi Ilemobola Solomon* \\ Department of Economics, Faculty of Social Sciences, Nigeria Defence Academy, Kaduna, Nigeria \\ Email address: \\ abrahamlex@gmail.com(Alexander.A. A.), adeyinka67@gmail.com(Olure-Bank A.M.), nikeolure@yahoo.co.uk(Olure-Bank A. M.), \\ ilemobolaoye@gmail.com (OyefabiI. S.) \\ ${ }^{*}$ Corresponding author
}

\section{To cite this article:}

Alexander Abraham Anfofum, Olure-Bank Adeyinka Michael, Oyefabi Ilemobola Solomon. Oil Consumption and Economic Growth in Nigeria: A Multivariate Cointegration Analysis. International and Public Affairs. Vol. 2, No. 1, 2018, pp. 11-22. doi: $10.11648 /$ j.ipa.20180201.12

Received: February 19, 2018; Accepted: March 9, 2018; Published: April 14, 2018

\begin{abstract}
The paper seeks to examine the relationship between oil consumption and economic growth in Nigeria using the Johansen and Juselius Co-integration technique based on the Cobb-Douglas production function to construct three models by introducing three major sectors of oil consumption of Nigeria (Transport, Power and Industrial sector oil consumption) and how Nigerian's upward review oil price variable impact on GDP. ADF (1979) and Johansen Maximum Likelihood method of cointegration (1988) are used to test the order of integration, Long run and short run dynamics between variable respectively using annual data since 1970-2016. The study shows an evidence of the long run and dynamic relationship for all the variables except industrial oil consumption and oil price variables which has no short run impact on GDP. Also it was found that capital and labour are more important in affecting output growth compared to energy consumption Oil prices impacting real GDP negatively in long run but positively in short run. Prominent policy recommendation are, in order to sustain high economic growth in the long-run, the country needs to increase the efficiency of its workforce and expand its saving capacity to generate more capital and need to strengthen the effectiveness of energy generating agencies by ensuring periodic replacement of wornout equipment in order to drastically curtail transmission power losses.
\end{abstract}

Keywords: Capital, Economic Growth, Labour, Oil Prices, Sectoral Oil Consumption, Oil Shocks, Johansen Maximum Likelihood Method

\section{Introduction}

The oil sector is a key sector in the Nigerian economy. This is because; the revenue from oil is the major growth factor in the Nigerian economy. Resources generated from it, fund virtually all capital expenditures in the Nigerian system. The oil sector is closely linked with the financial sector, because the financial sector in every country is the oil which fuels the economy of such country and the bedrock for the sustenance and continuity of the sovereignty of a country. The impact of the oil price fall is disastrous on the Nigerian economic system; consumers are feeling the hit through escalating price of goods and commodities, massive sack of workers in the labor force among others. Therefore, there is a need for Nigeria to look inwards amidst the abundance of its untapped natural resources to diversify the economy of the nation, and increase export with a view to checkmating the insidious impact of the oil price fall on the economy Since 1980s oil demand has increased rapidly in all over the world because of world oil price has driving down. Existing literature has suggested many possible impacts of oil shocks on the economic growth. Increase in the oil price cause increase in the production cost, import bills and price of petroleum products, so the decline in the productivity due to increasing cost of input (oil) cause decline in the consumption level, investment and consequently in economic growth. So oil price shocks limit the world over, the sustainability of any economic growth is to a large extent depend on the diversification of such economy. In the developed society fallen oil prices is not a threat as several measures are in place to upturn such occurrences. Arguably, Nigeria is a mono-product economy, remains susceptible to the movements in international crude oil prices it is also contends that oil plays a critical role in Nigeria in the conduct of fiscal and monetary policies because it 
accounts for average of $80 \%$ of government revenue, $90-95 \%$ of the foreign exchange earnings and $12 \%$ of the real gross domestic product. Despite such windfall, Nigeria has an increasing proportion of impoverished population and experienced continued stagnation of the economy (OkonjoIweala and Osafo-Kwaako, 2007). Oil consumption which can rise or lessen the economic growth. Consumption of energy plays vital role in enhancing the growth of economy. Oil consumption plays crucial role in every sector of economy i.e. transport, power sector and industrial sector. There is difference in results of causal relationship related to energy-growth model of developed and developing country like Nigeria. "Nigeria exporting oil is one of the finest, sweetest and most qualitative in the world, but importing refine oil which are the crudest and worst quality into Nigeria. We are producing the best quality oil, we are consuming the worst quality oil because instead of refining oil in our refineries in Warri, Port-hecut and Kaduna, Nigeria kept her refineries idle, and importing the abandoned oil from abroad". Since the discovery of oil, the Nigerian nation has depended too heavily on the capital intensive oil sector which contributes 20 percent to the GDP, 95 percent of the foreign exchange and 65 percent of budgetary revenue (Sunday Tribune, July 1, 2007:9).

Nigeria is thus a mono-cultural dependent capitalist economy in a permanent crisis of various sorts, including micro and macroeconomic instability as a result of a systematic implementation of Bretton-wood economic policies contained in the so-called NEEDS document. Government is very rich, but our people are poor because of economic policies of government and unless we pursue industrialization the free market economy cannot help us. Unless we allow government to be the leader of the economy, the private sector cannot succeed. Some people are saying that the private sector is the engine of the economy; yes that is correct only where there is viable, feasible and effective private sector like in industrialized nations.

Nigeria economy can be structurally classified into three major sectors: primary sector-agriculture and natural resources extraction; secondary sector-processing and manufacturing; and tertiary sector-trade and services. Both the government and the private sectors operate on these major sectors of the economy. For sustainable development, these sectors are expected to grow and blend with each other. But this is not the case in Nigeria as there are poor infrastructures and human capacity to integrate them. The primary sector's produce gets to the tertiary sector or end user with little or no input from the secondary sector. The secondary sector which should consolidate and give enhanced value to primary sector's produce to boast the economy is poorly developed. Most of the primary sector's produce like agricultural and natural resources extractions do not go to the secondary sector (processing and manufacturing) which enhances their value, before getting to the market or the end users. Hence, primary goods get to their end user in the raw state attracting low economic value. This lack of effective participation of the secondary sector in the economic chain impoverishes the nation, the reason are due to the high cost of oil as all firms generate electric energy to power there equipment's these as lead to major firms living the nation for other nation were energy are cheaper, which exposes the nation to exploitation and slows down economic development and stability. The primary sector dominates the nation's economy. Between 1960 and 2009, it contributes 62.1 percent of her GDP. The secondary sector (manufacturing and building/construction) contributes average of 9.6 percent, and the tertiary sector (trade and services) contributes an average of 28.3 to the nation's GDP (Sanusi, 2010). The secondary sector needs a boast for it to achieve its role for optimal utilisation of the nation's resources and integration of the economy. The high hope of rapid development and industrialisation of the nation that accompanied her independence in 1960 has been crushed. The collapse of essential infrastructure for economic and industrial activity like electricity, transportation, good road, portable water, investable fund; and inconsistent government policies on stimulation of industrial activities have discouraged the springing up of industries despite the fact that Nigeria with her large population and vast land is well suited to be the economic hub center of Africa. Nigeria needs to utilise its large human and natural resources to develop the industrial sector for optimal utilisation of the resources and sustainable economic stability.

Nigerian who is also a major importer of refine oil and oil products is depending heavily on the oil as input to generate energy in industrial, transport and electricity sector. As many developing countries generate electricity from cheap sources like water, wind etc, but in Nigeria oil and gas are the major source to produce electricity that is costly input. In Nigeria there few studies conducted that estimate relationship between use of oil and economic growth specifically. In the study three stage Granger causality test and ECM approach are used to test causality relationship and Johansen cointegration test for cointegration analysis. Again in the study oil prices or oil price shock variable is include, as it is very important factor to effect the economic growth. The core objective is to analyze the impact of oil prices and oil price shocks on economic growth. We also investigate impact of other shocks on economic growth of Nigerian. The other objective of the study is to investigate the impact of oil consumption on economic growth of Nigerian by using cointegration analysis and dynamic Error Correction Model. The study is arranged as follows: the section 2 An overview of Nigeria and it oil economy, section 3 illustrates the methodology which includes sources of data and explanation of Augmented Dickey Fuller test, Johansen cointegration by Maximum Likelihood Method section 4 explains the results and discussion of the analysis. Finally section 5 demonstrates the conclusions and section 6 the recommendation of the study.

\section{Literature Review}

\subsection{An Overview of Nigeria and It Oil Economy}

Nigeria has large quantity of over 37 types of solid 
minerals spread across her vast land. Like agriculture, the exploitation of these minerals is neglected and left in the hands of local peasants who lack both the fund and expertise for their efficient and economic exploitation. The solid minerals can also contribute meaningfully to the nation's GDP and be a major foreign revenue earner if given the necessary attention. Petroleum industry is the only sector that has been striving in Nigeria. It has "pushed Nigeria to the forefront of the global industry, making the country the sixth largest exporting and seventh largest producer of oil in the world" (Aigbedion and Iyayi, 2007). According to Sanusi (2010) of the Central Bank of Nigeria, Nigeria has the sixth largest gas reserves and the eighth largest crude oil reserves in the world. Despite Nigeria's high profile in the extraction and export of crude petroleum, the downstream sector of the industry is yet to develop. Nigeria still imports a substantial amount of refined oil for her domestic need. The other petrochemical industries that should accompany the oil industry are lacking. It is unfortunate that the huge oil extraction in the nation does not translate into development of petroleum allied industries and stimulation of diversity of the economy.

According to Adedipe (2004), when Nigeria gained politically independence in October 1960, agricultural production was the main stay of the economy, contributing about $70 \%$ of the Gross domestic product (GDP), also employing about seventy percent of the working population and responsible for about ninety percent of foreign government revenue. The initial period of post-independence till mid 1970s witness a fast advancement of industrialized capacity and output, as the contributions made by the manufacturing sector to GDP rose from 4.8 percent to 8.2 percent; this pattern changed as crude oil became important to the world economy. In the words of Englama et al (2010), as crude oil became an export commodity in Nigeria in 1958, following the discovery of the first producible well in 1956; the contribution of oil to the federal government revenue rose from 26.3 percent in 1970 to 82.1 percent in 1974 and in 2008 constituted 83 percent of the federal government revenue, largely on account of increase in oil prices in the international market. The gigantic rise in oil revenue was caused by the Middle East war of 1973. It created extraordinary, surprising and unforeseen wealth for Nigeria and the naira appreciated as foreign exchange influxes offset outflows and Nigeria foreign reserves assets increased (Adedipe, 2004). The economy of Nigeria gradually became dependent on crude oil as productivity declined in other sectors (Englama et al, 2010).

Since the discovery of Oil in commercial quantity, Nigeria has been a mono-product economy. The value of Nigeria's total export revenue in 2010 stood at US\$70,579 million, while income from petroleum exports of the total export revenue was US\$61,804 million representing about 87.6 percent. The absolute dependence of oil export revenue has accentuated the level of Nigeria economy vulnerability to sudden oil price movements.

Factors such as periods of favorable oil price shocks triggered by conflict in oil-producing countries of the world, rise in the demand for the commodity by the consuming nations due seasonality factors, trading positions etc; enhance Nigeria favorable terms of trade evidenced by her experiences of large current account surplus and exchange rate appreciation. On the converse, when crude oil prices are low, occasioned by factors such as low demand, seasonality factors, excess supply, the Nigeria experiences unfavorable terms of trade evidenced by budget deficit and slow economic growth (Englama, 2010). An example was a drop in the revenue from oil exports during the global financial crisis in 2009. According to, OPEC statistical bulletin (2010/2011), oil export revenue dropped from US\$74,033 million in 2008 to US\$43,623 million in 2009 and the naira depreciated to N148.902 in 2009 from N118.546 in 2008.

From the period of the oil boom of the 1970s till now, Nigeria has neglected her strong agriculture and light manufacturing bases in favor of unhealthy dependence on crude oil. New oil wealth has led to a concurrent decline of other sectors in the economy and has fueled massive migration to cities and led to increasingly wide spread poverty especially in rural areas. As a result, Nigeria's job market has witnessed very high degree of unemployment, small wage and pitiable working environments (Adedipe, 2004 and Odularu 2007). Between 1970 to 2000, Nigeria's poverty rate increased from 36 percent to just fewer than 70 percent and it is believed that oil revenue did not seem to add to the standard of living at this time but actually caused it to decline (Martin and Subramanian, 2003).

Nigeria's resource endowment is not disputable; the country is ranked as the largest oil producer in Africa and occupies the 13 th position in the world. It has a proven crude oil reserve of 37,062 million barrels, natural gas reserve of 5,284.3 billion cu m (OPEC Annual Statistical Bulletin, 2016) Thus, its reserve base is ranked the 10th in the world and 2nd largest in Africa. Following the rebasing of the country's GDP, it became the largest economy in Africa. Despite Nigeria's richness and occupies the 13th position in the world. It has a proven crude oil reserve of 37,062 million barrels, natural gas reserve of 5,284.3 billion cu m (OPEC Annual Statistical Bulletin, 2016) Thus, its reserve base is ranked the 10th in the world and 2nd largest in Africa. Following the rebasing of the country's GDP, it became the largest economy in Africa. Despite Nigeria's richness in both human and material resources, the country still grapples with myriad of economic challenges that have continued to impede her journey on the path of economic growth. Presently, the country is highly dependent on crude oil for export and as major revenue source consequently annual budgets are usually prepared and tied to a given expected price and production level of crude oil. This has put the economy in a vulnerable position and exposes it to the vagaries of changes in crude oil prices. In an attempt to mitigate the negative impact of such exposure on the Nigerian economy, the Obasanjo's administration in 2004 introduced the Excess Crude Account to protect planned budgets against short-falls arising from changes in crude oil 
prices. Although this initiative helped to cushion the effects of falling oil prices during the global financial crisis of the 2007-2009 when the price of crude oil dropped drastically, the package could not be sustained. Successive governments continued to spend even when oil prices improved leading to the depletion of excess crude account with no savings left for rainy days. The recent crash in oil prices undoubtedly plunged the largest economy in Africa into an economic rise while the exchange rate continued to depreciate, causing enormous economic difficulties among the populace. Interesting, as crude oil price is falling at the global market, domestic pump price of petrol in Nigeria suffered distortion and upward review.

\subsection{Conceptual Review}

Energy is capacity to perform work as the result of its motion or its position in relation to forces acting on it. (Encarta, 2009). We use energy for everything we do, from making a jump to sending astronauts into space. The same concept according to Tejada-Bailly (1981) can be expressed as the amount of heat that must be transferred, exchanged or used up to effect a process or deliver a good to a particular point in the economic system. Energy exists in various forms, including atomic, electrical, chemical, mechanical, nuclear, radiant and thermal. Although energy can be transferred from one form to another but it cannot be created or destroyed. Energy can be extracted from a variety of resources that can be categorized as primary and secondary; commercial and non-commercial; conventional and nonconventional; renewable and non-renewable and traditional and nontraditional. Below gives example of some energy sources and resources.

Sources of energy Nonrenewable energy sources Renewable energy sources Secondary energy sources Oil and petroleum products, Diesel fuel - Propane - Gasoline Natural gas Coal Nuclear - Uranium - Deuterium - Radium - Thorium - Tritium

Hydropower Biomass - Phytomasseg wood peat - Animal dung - Agricultural wastes - Charcoal - Agricultural crops Ethanol Biodiesel Wind Geothermal Solar - Radiation Photovoltaics - Photosynthesis - Flat-Plates collectors Electricity Source: Tejada-Bailly (1981) and EIA (2012)

If we examine the international studies review of oil consumption, growth and prices it can be seen that literature in context to energy-growth has been initiated with the study of Kraft. It is notice that most study seem interested in finding the causal relationship between energy consumption and economic growth. Many initial studies have done bivariate analysis in this respect, which could generate biased results due to omission of relevant variables. Afterward more complex studies had examined aggregate as well as at disaggregate level studies on oil consumption analysis but only few studies are available on multivariate analysis like Levent and Korap, panel data analysis using Hasio Granger causality test as well as Chenge and Lai, maximum likelihood method of cointegration by Johansen and VECM approach and Soytas and Sari, were used in recent international papers. But these studies generated different results from each other even for same sample data as Akarca and Long, only very few studies include the important of oil shocks factor in their analysis as in Bekhet and Yusop, these results could be different due to different techniques, different sample data, times series properties of the data and different country. So results could be different, although at international level, few studies have used advanced econometric techniques. If we look up the studies in context of Nigeria, numbers of studies could be found on the issue of energy-growth, in case of Nigeria there are studies at aggregate energy level but at disaggregate level of energy studies only few are available that are specifically on oil or gas consumption and economic growth. If we examine the previous study of Bright Orhewere and Machame Henry (2011), one of the study in Nigeria that had investigated the relationship between oil consumption and economic growth in Nigeria. In the study oil price variable and shock dummies were not included that could have significant impact on the economy. Oil consumption variables are positively cointegrated with economic growth in Bright Orhewere and Machame Henry (2011). But oil consumption variables (including oil sectors) show unidirectional causal relationship by using pair wise Granger causality test. In this study Johansen cointegration test is used all variables are cointegrated. But these results could be biased by estimating single dynamic equation for aggregate as well as aggregate oil consumption due to multicoliniearity. But in our study dynamic model for total oil consumption will be estimated. Also oil shocks factor that has been ignored will be added in our study it will show the important of oil consumption and growth of economy.

So from review study different cointegration and causality relationships are observed from different papers on energy and economic growth including oil consumption- economic growth analysis. Most of studies show that energy (oil consumption) has positive impact on the overall economy.

\section{Theoretical Framework and Methodology}

The theoretical framework of this study is based on ADF (1979) and Johansen Maximum Likelihood method of cointegration (1988) are used to test the order of integration modeled by Nazir S and Hameed T (2015).

The models used Neo classical production function $[\mathrm{Y}=\mathrm{f}$ $(\mathrm{K}, \mathrm{L})$ ] for this study, that is put forward by Cobb-Douglas, and modified by including energy variables for energygrowth model. Neoclassical economist gave the theory of output (production) function as fellows;

$$
\mathrm{Y}=\mathrm{f}(\mathrm{K}, \mathrm{L})
$$

Georgescu-Roegen was the pioneer to remark on the lack of energy variable in the model. The Kraft and Kraft was first to use energy consumption variables in production function to analysis the energy-growth relationship. After that many 
studies use it in their study, Energy consumption plays very important part on the economy as labor and capital do. In this study oil price of Nigeria is introduced into the model as Bekhet and Saibu used it in their study. Oil prices significantly impact on GDP, consumption and overall economy. Ahmed has explained various transmission mechanisms for possible impact of oil price shocks on economic growth. First is the classic supply size effect, according to which, increase in oil prices leads to decline in the output level, because oil is considered as the basic input of the production. Higher oil prices would result in the higher output costs, results in lowered production rate and declined growth rate. Second, the demand side effect discusses the adverse effect of oil price shocks on investment and consumption. The major input for the industries is capital that comes from the investments of local and foreign investors. When economic activities are at decline, investors withdraws their investments from markets and take money out of the country and invest in higher profitable and growing economies, resulting in further lowering of production and economic activities in the country. Also Akram introduced oil price variable in the production function in his study. So above model is modified as follows:

$$
\mathrm{LY}_{\mathrm{t}}=\mathrm{f}\left(\mathrm{LK}_{\mathrm{t}}, \mathrm{LL}_{\mathrm{t}}, \mathrm{LP}_{\mathrm{t}}, \mathrm{LOC}_{\mathrm{t}}, \mathrm{D}_{\mathrm{t}}, \mu_{\mathrm{t}}\right.
$$

Where;

$\mathrm{LY}_{\mathrm{t}}=$ Log of Gross domestic product, real data of GDP taken as the proxy of economic growth.

$\mathrm{LK}_{\mathrm{t}}=\mathrm{Log}$ of gross fixed capital formation divided by GDP is used as the proxy of the capital stock $(\mathrm{K})$ as many paper has used this proxy for capital stock $(\mathrm{K})$,

$\mathrm{LL}_{\mathrm{t}}=\mathrm{Log}$ of labor force.

$\mathrm{LP}_{\mathrm{t}}=\mathrm{Log}$ of average oil prices of Nigeria.

$\mathrm{LOC}_{\mathrm{t}}=\mathrm{Log}$ of oil consumption that includes three major sectors (transport, power sector and industrial sector) of Nigeria.

$\mathrm{D}_{\mathrm{t}}=$ Dummy variable for in cooperating the effect of oil prices shocks on Nigeria's economy.

$\mu_{\mathrm{t}}=$ Error term, that is normally distributed with zero mean and constant variance $(0, \sigma 2)$.

It is assume that all variables are non- stationary and have long run relationship between economic growth and its determinant. General model of this study was specified above in equation (2).

For the next analysis of this study there is needed to construct the vector auto regressive (VAR) model constructed for equation (2) given below in equation (3):

$$
\begin{gathered}
\mathrm{X}_{\mathrm{t}=} \sum_{i=1}^{k} \delta X_{t-1} \gamma D_{t}+\propto+\mu_{\mathrm{t}} \\
\therefore \mu_{t} \sim N(0, \mu \sigma)
\end{gathered}
$$

Where, $X_{t}$ is vector of variables (i.e. LY, LL, LK, LP, LOC) a $5 \times 1$ vector of integrated of order one I(1) taken as endogenous variables, $D_{t}$ is the vector of exogenous variables, $\alpha$ is constant and $\mu_{\mathrm{t}}$ is iid $(0, \sigma 2)$.

Assuming the variables are non-stationary and they have long run relationship among each other, we specify dynamic ECM model as:

$$
\begin{gathered}
\Delta \mathrm{X}_{\mathrm{t}}=\mu_{\mathrm{t}}+\gamma_{\mathrm{t}}+\sum_{t-1}^{p} \Gamma_{t} \Delta \mathrm{X}_{\mathrm{t}-1}+\prod_{E C M_{\mathrm{t}-1}+\lambda \mathrm{D}_{\mathrm{t}}+\mathrm{v}_{\mathrm{t}}} \\
\therefore \mu_{t} \sim \mathrm{N}\left(0, \sigma^{2}\right)
\end{gathered}
$$

In equation (4), $\Pi=\alpha \beta^{\prime}$ and $\alpha$ is speed of adjustment of matrix and $\beta^{\prime}$ is matrix of long run coefficients. $\Pi \mathrm{X}_{\mathrm{t}-1}$ integrated of order zero I (0) and negative for having long cointegration relationship.

$\sum_{i-1}^{p} \Gamma_{t} \Delta X_{t-1}$ this term of model indicates short run part. $\lambda$ indicates coefficient of shock dummies, $\gamma$ coefficient of time trend of model $\mu$ and $v_{t}$ are intercept and error term of the model respectively that are normally distributed as zero mean and constant variance.

Through the value of $\Pi$ it can be shown that with how much speed model is converges toward equilibrium or we can say that error is correcting with speed of the $\Pi$. Its value also confirms our long run relationship. ECM models of three sectoral oil consumption of Nigeria are given below; these are estimated for finding the results of our study:

\subsection{Transport Oil Consumption and Growth}

$$
\begin{gathered}
\Delta L Y_{t}=\beta_{0}+\text { trend }+\prod_{1} \text { ECMt }-1+\sum_{i=1}^{m} \beta_{1 i} \Delta L Y_{t-1}+\sum_{i=1}^{n} \beta_{2 i} \Delta L K_{t-1}+\sum_{i=1}^{0} \beta_{3 i} \Delta L L_{t-1}+\sum_{i=1}^{p} \beta_{4 i} \Delta \mathrm{LPt}-1+ \\
\sum_{i=1}^{q} \beta_{5 i} \Delta L T R A N S P_{t-1}+\emptyset D_{i}+\mu_{0 t}
\end{gathered}
$$

The second dynamic model for transport oil consumption and growth is given above. So the expected relationship between the variables could be,

$\beta_{0}>0, \beta_{1 i}>0, \beta_{2 i}>0, \beta_{3 i}>0, \beta_{4 i}>0, \beta_{5 i}>0, \prod_{1}$ and $\emptyset<0 . \mu 0 t$ error term of the dynamic model normally distributed as 2 $\left(0, \sigma^{2}\right)$.

\subsection{Power Sector Oil Consumption and Growth}

$$
\begin{gathered}
\Delta L Y_{t}=\delta_{0}+\text { trend }+\prod_{1} \text { ECMt- } 1+\sum_{i=1}^{m} \delta_{1 i} \Delta L Y_{t-1}+\sum_{i=1}^{n} \delta_{2 i} \Delta L K_{t-1}+\sum_{i=1}^{0} \delta_{3 i} \Delta L L_{t-1}+\sum_{i=1}^{p} \delta_{4 i} \Delta \mathrm{LPt}-1+ \\
\sum_{i=1}^{q} \delta_{5 i} \Delta L P W G_{t-1}+\theta D_{i}+\mu_{0 t}
\end{gathered}
$$

Dynamic model for power sector oil consumption and growth will be estimated as above.

Whereas anticipated relationship between variables might be,

$\delta_{0}<0, \delta_{1 i}>0, \delta_{2 i}>0, \delta_{3 i}>0,{ }_{4} \delta_{i}>0, \delta_{5 i}>0, \prod_{1}$ and $\theta<0 . \mu 0 t$ error term of the dynamic model normally distributed as
$\left(0,{ }^{2}\right)$.

$\delta_{0}$
$\left(0,{ }^{2}\right)$. 


\subsection{Industrial oil Consumption and Growth}

$$
\begin{gathered}
\Delta L Y_{t}=\lambda_{0}+\text { trend }+\prod_{1} \text { ECMt }-1+\sum_{i=1}^{m} \lambda_{1 i} \Delta L Y_{t-1}+\sum_{i=1}^{n} \lambda_{2 i} \Delta L K_{t-1}+\sum_{i=1}^{0} \lambda_{3 i} \Delta L L_{t-1}+\sum_{i=1}^{p} \lambda_{4 i} \Delta \text { LPt } 1+ \\
\sum_{i=1}^{q} \lambda_{5 i} \Delta L P W G_{t-1}+\omega D_{i}+\mu_{0 t}
\end{gathered}
$$

Finally, the dynamic model for industrial oil consumption and growth will be estimated as above. While the possible relationship between variables can be, $\lambda_{0} \lesseqgtr 0, \lambda_{1 i}>0, \lambda_{2 i}$ $>0, \lambda_{3 i}>0,{ }_{4} \lambda_{i}>0, \lambda_{5 i}>0, \prod_{1}$ and $\omega<0 . \mu 0 t$ error term of the dynamic model normally distributed as $\left(0,{ }^{2}\right)$.

In above three dynamic models; $\beta$ 's, $\delta$ 's and $\lambda$ 's are short run coefficients of variables in each model. $\Pi_{1}, \Pi_{2}$ and $\Pi_{3}$ are coefficients of $\mathrm{ECM}_{\mathrm{t}-1}$ of all four models respectively. $\phi, \theta$, and $\omega$ are coefficient of shock dummies.

\subsection{Estimation Techniques}

The study use the following for it finding. Step I: Unit root test is important for cointegration analysis. To check the order of integration for variables whether they are stationary $\mathrm{I}(0)$ or non-stationary I(1) for analysis of Johansen cointegration as all variables should be non-stationary at same order for example integrated of order one I(1). Dickey and Fuller give one of the generally used methods known as Augmented Dickey Fuller (ADF) test of identifying the order of integration I(d) of variables whether the time series data are stationary or not. Equation (6.8) is the general form of Augmented Dickey Fuller test that will be used to check the stationary of series.

$$
\Delta \mathrm{X}_{\mathrm{t}}=\alpha+\beta_{\mathrm{t}}+\emptyset \Delta \mathrm{X}_{\mathrm{t}-1}+\theta_{1} \Delta \mathrm{X}_{\mathrm{t}-1}+\theta_{2} \Delta \mathrm{X}_{\mathrm{t}-1 \ldots \ldots} \theta_{\mathrm{p}} \Delta \mathrm{X}_{\mathrm{t}-1} \varepsilon_{\mathrm{t}}
$$

Where, $X_{t}$ denotes the time series variable to be tested, used in model.

$\mathrm{t}$ is time period,

$\Delta$ is first difference and $\varphi$ is root of equation.

$\mathrm{B}_{\mathrm{t}}$ is deterministic time trend of the series and $\alpha$ denotes intercept.

Numbers of augmented lags (p) determined by the dropping the last lag until we get significant lag. Augmented Dickey Fuller unit root concept is illustrated through equation $\Delta X_{t}=(\rho-1) X_{t-1}+\varepsilon_{t}$, Where, ( $\left.\rho-1\right)$ can be equal to $\varphi$, if $\rho=1$ so series has the unit root, so root of equation is $\varphi=0$.

Step II: If combination of two non-stationary variables generates linear combination, they are cointegrated. So Johansen presented the Maximum Likelihood Method for estimating more than one cointegration vector. But for this test, all variables should have same order of integration I (d) i.e. I (1). The method of Maximum Likelihood estimation is use to estimate long run coefficients and to find the order of cointegration using two test statistics Maximum Eigenvalue test and Trace test.

Step III: The dynamic models of sectoral oil consumption of Nigeria have will be estimated using ordinary least square (OLS) method, to get reliable results the model should be well specified and should meet all assumptions of OLS statistically, otherwise our results could be spurious or misleading. Residual of the model is diagnosed for serial correlation through Breusch Godfrey LM test, to check for hetroscadasticity we use Breusch Pagan. For the normality of the residual of the model Jarque Bera test will be applied. To examine the data goodness of fit and how independent variables explained the dependent variable $R^{2}$ and adjusted $\mathrm{R}^{2}$ value is tested. For the estimation of model above five macroeconomic variables are identify in previous literature. Annual time series data of all variables from 1970 to 2016. Data for GDP, Gross Fixed Capital Formation (K) and Labor force (L) are obtain from federal bureau of statistics, total oil consumption (TOC) data taken from department of petroleum and Oil prices (P) data taken from the CBN statistical bulletins of Nigeria.

\section{Estimated Results and Discussion}

After all data are transformed into logarithm form. Augmented Dickey Fuller test was conducted on the all variables, the time trend will be included in the model. Intercept is also included in the model because by examining the figures of series it can be noticed that data doesn't fluctuate around the zero mean. The average of sample is also not zero so that's why intercept will be included. These are only assumptions to check that these are true or not in other words data is stationary or non- stationary (Table 1). First, the equation of ADF (with drift and time trend in the model) has estimated, for all the variables. At first, unit root was tested at level or without differencing the data. For oil prices, transport and power sector oil consumption lags are

\begin{tabular}{|c|c|c|c|c|}
\hline \multicolumn{5}{|l|}{ At Level } \\
\hline Variable LY & $\begin{array}{l}\text { Deterministic } \\
\text { Intercept }\end{array}$ & Lags 0 & $\begin{array}{l}\text { ADF stat } \\
-2.48\end{array}$ & $\begin{array}{l}\text { Outcome } \\
\text { I(1) }\end{array}$ \\
\hline LK & Intercept & 0 & -2.07 & $\mathrm{I}(1)$ \\
\hline LL & $\begin{array}{l}\text { Intercept and } \\
\text { trend }\end{array}$ & 0 & -1.61 & $\mathrm{I}(1)$ \\
\hline LP & $\begin{array}{l}\text { Intercept and } \\
\text { trend }\end{array}$ & 0 & -2.52 & $\mathrm{I}(1)$ \\
\hline LTRANS & none & 1 & -1.94 & $\mathrm{I}(1)$ \\
\hline LIND & Intercept & 0 & -1.46 & $\mathrm{I}(1)$ \\
\hline LPWG & $\begin{array}{l}\text { Intercept and } \\
\text { trend }\end{array}$ & 1 & -1.67 & $\mathrm{I}(1)$ \\
\hline \multicolumn{5}{|c|}{ First Difference } \\
\hline Variable & Deterministic & Lags & $\begin{array}{l}\text { ADF - } \\
\text { stat }\end{array}$ & Outcome \\
\hline$\Delta \mathrm{LY}$ & Intercept & 0 & -4.20 & $\mathrm{I}(0)$ \\
\hline$\Delta \mathrm{LK}$ & Intercept & 0 & -3.87 & $\mathrm{I}(0)$ \\
\hline$\Delta \mathrm{LL}$ & Intercept & 0 & -6.53 & $\mathrm{I}(0)$ \\
\hline$\Delta \mathrm{LP}$ & Intercept & 1 & -5.76 & $\mathrm{I}(0)$ \\
\hline$\triangle \mathrm{LTRANS}$ & $\begin{array}{l}\text { Intercept and } \\
\text { trend }\end{array}$ & 0 & -5.44 & $\mathrm{I}(0)$ \\
\hline$\triangle \mathrm{LIND}$ & None & 0 & -4.01 & $\mathrm{I}(0)$ \\
\hline$\triangle \mathrm{LPWG}$ & None & 0 & -4.12 & $\mathrm{I}(0)$ \\
\hline
\end{tabular}
taken to remove the problem of serial correlation

Table 1. Unit Root Test of Augmented Dickey Fuller (Annual Data). 
Table 2. VAR Lag Order Selection for TRANP and Growth.

\begin{tabular}{lllllll}
\hline Lag & LogL & LR & FPE & AIC & SC \\
\hline 0 & 335.611 & NA & $5.61 \mathrm{E}-14$ & -16.25742 & -15.29006 & -15.6641 \\
1 & 558.4849 & $328.3379 *$ & $1.78 \mathrm{e}-18^{*}$ & -26.76663 & $-24.61291 *$ & $-25.99189 *$ \\
2 & 586.4589 & 33.9823 & $1.78 \mathrm{E}-18$ & $26.91889^{*}$ & -23.68681 & -25.76894 \\
\hline
\end{tabular}

*indicates significant lag at 5\% level.

Table 3. Trace and Max Eigenvalue Test of Cointegration for TRANP and Growth.

\begin{tabular}{lllll}
\hline Hypothesis & & & Test statistics & Critical values \\
\hline & $\mathrm{H}_{0}$ & $\mathrm{Ha}$ & & $5 \%$ \\
& $\mathrm{r}=0$ & $\mathrm{r} \geq 1$ & $101.0587^{*}$ & 69.81889 \\
& $\mathrm{r} \leq 1$ & $\mathrm{r} \leq 2$ & $50.68022^{*}$ & 47.85613 \\
$\lambda$ trace $)$ & $\mathrm{r} \leq 2$ & $\mathrm{r} \leq 3$ & 18.78234 & 29.79707 \\
& $\mathrm{r} \geq 3$ & $\mathrm{r} \leq 4$ & 2.892517 & 15.49471 \\
& $\mathrm{r} \geq 4$ & $\mathrm{r} \geq 5$ & 0.716806 & 3.841466 \\
& $\mathrm{r}=0$ & $\mathrm{r}=1$ & $50.37852^{*}$ & 33.87687 \\
$(\lambda \max )$ & $\mathrm{r} \leq 1$ & $\mathrm{r}=2$ & $31.89788^{*}$ & 27.58434 \\
& $\mathrm{r} \leq 2$ & $\mathrm{r}=3$ & 15.88982 & 21.13162 \\
& $\mathrm{r} \leq 3$ & $\mathrm{r}=4$ & 2.175711 & 14.26460 \\
& $\mathrm{r} \leq 4$ & $\mathrm{r}=5$ & 0.716806 & 3.841466 \\
\hline
\end{tabular}

*indicates significant at $5 \%$

Dickey Fuller test become Augmented Dickey Fuller test, otherwise it is Dickey Fuller test. It can be seen from the table that at level, variables are not stationary. So LY, LL, LP, LK LPWG, LTRANP and LIND are stationary at first difference. Therefore, all variables are integrated of order one, I (1).

\subsection{Dynamic Analysis for Transport Oil Consumption and Growth}

Cointegrating analysis:

Applying the Johansen cointegration test on first model that includes transport oil consumption in Nigeria. The VAR model has estimated with five variables (LY, LP, LTRANP, LL and LK) and two exogenous pulse dummies and one step dummy of 2005. 1979 dummy is added for capture the effect of Iranian oil revolution, 2008 for global financial crisis and 2005 for oil prices increase up to $\$ 50$ per barrel due to decline in the supply of oil from Iraq and great earth quack in Nigeria. Both dummies influence significantly. Results of Lag length selection criteria are given in the Table 2 . We can see in the Table 2 that, LR, FPE, SC and HQ criteria indicate the first lag for estimating the VAR at 5\%. When the significant lag is selected the VAR model estimated with one lag. In the model we include the unrestricted trend and intercept in the model but no trends in cointegration regression. As discussed in the Johansen, Johansen and Juselius five different choices of intercept and trend (Table 2). Long run relationship between the variables was examined with Trace test and Maximum Eigenvalue test given by Maximum Likelihood Method. These results are given in the Table 3 . According to the Trace test statistics the null hypotheses $r=0$ and $r \leq 1$ is rejected at $5 \%$ against the alternative hypotheses $r \geq 1$ and $r \leq 2$. Through the Maximum Eigenvalue test statistics the null hypotheses $r=0$ and $r \leq 1$ is rejected at $5 \%$ against the alternative hypotheses $r=1$ and $r=$ 2 (Table 3). Both test statistics indicates two log run cointegrating relationships within the variables for this model. But in this study we take only one cointegrating vector for further analysis now we estimate the cointegration relationship by using Maximum Likelihood Method. Normalized coefficients are given below in equation (9). (Chi square values are in parenthesis.).

$$
\mathrm{LY}_{\mathrm{t}}=-\frac{4.47 \mathrm{LKt}}{(46.5)}+\begin{gathered}
14.33 \mathrm{LLt} \\
(74.30)
\end{gathered}+\begin{gathered}
3.96 \mathrm{LTRANPt} \\
(28.19)
\end{gathered}-\begin{gathered}
4.38 \mathrm{LPt} \\
(52.70)
\end{gathered}
$$

Oil consumption in transport sector form the major part of total oil consumption Nigeria. Almost $49 \%$ of total oil consumption are used in the transport sector in 2011. Observing the above normalize long run equation (9) labor force shows significantly positive impact on the GDP of Nigeria as expected but capital stock shows negative impact on GDP. Negative relationship is due to inefficient investment in different sectors of economy also due to shortage of capital stock to influence positively on GDP. The oil price shows significant negative impact on GDP, showing $4.38 \%$ negative change in the GDP due to one percent change in the oil prices. Due to circular debt problem created by the oil price shock which creates negative impact on economic growth. Nigerian's imports mostly are petroleum or petroleum products with the upward review of it price oil is the costly input product and impacted the economic growth. In past years of Nigeria the oil consumption especially in transport sector has decreased growth by almost $0.97 \%$. The consumption of oil is not efficient in the Nigeria so it negatively impact on the overall economy or GDP. There is positive relationship between the GDP and transport oil consumption in long run, there is $3.96 \%$ change in the GDP due to one percent positive change in the transport oil consumption. These results satisfy the theory having positive relationship between GDP and consumption. Short run dynamic results: Parsimonious Error Correction Model (7.2) for transport oil consumption and growth estimated the general to specific approach at lag one selected on the basis of diagnostic tests. (t-statistics values in parenthesis).

$$
\Delta \mathrm{LY}_{\mathrm{t}}=\frac{0.07}{(5.90)}-{ }_{(-2.74)}^{0.003_{\mathrm{t}}}-\underset{(-2.20)}{0.36 \Delta \mathrm{LY}_{\mathrm{t}-1}}+\underset{(4.09)}{0.18 \Delta \mathrm{LK}_{\mathrm{t}}}-\underset{(-2.79)}{0.47 \Delta \mathrm{LL}_{\mathrm{t}-1}}+\stackrel{0.16 \Delta \mathrm{LTRANP}_{\mathrm{t}}}{(4.27)}-\begin{gathered}
0.02 \mathrm{D} 1981 \\
(2.88)
\end{gathered}+\begin{gathered}
0.02 \mathrm{D}_{1988} \\
(3.19)
\end{gathered}+\begin{gathered}
0.004 \mathrm{D}_{2005} \\
(4.32)
\end{gathered}-\begin{gathered}
0.02 \mathrm{ECM}_{\mathrm{t}-1} \\
(-3.99)
\end{gathered}
$$


Diagnostic tests:

$\mathrm{R}^{2}=0.63$, Adjusted $\mathrm{R}^{2} 0.54$

Breusch Godfrey LM test of Autocorrelation $\mathrm{F}_{(1,27)}=0.02$ (0.86), Jarque Bera test of Normality $\chi 2(2)=0.81(0.66)$, Breusch Pagan Godfrey Hetroscadasticity test $\mathrm{F}_{(9,28)}=$ 0.86(0.56),

Diagnostic tests of first dynamic model (10) are identified here, first by proving the no serial correlation through LM test. The value of $F$ statistics is 0.02 so we cannot reject the null hypotheses of no serial correlation. The chi square $\chi 2$ value of Jarque Bera is 0.81 tells that residual follow the normal distribution as we cannot reject the null of hypothesis and also the residual have equal spread of variance by examining the $\mathrm{F}$ statistics of hetroscadasticity test that is 0.86 . The $\mathrm{R}^{2}$ and adjusted $\mathrm{R}^{2}$ shows that independent variables are explained $63 \%$ and $51 \%$ by dependent variable respectively. However, by examining the dynamic model it can be noticed that, the magnitude of $\mathrm{ECM}_{\mathrm{t}-1}$ is negative and significant according to theory, in equation (10). The value shows the error is adjusting with the speed of $0.02 \%$ in the one year. We can see that the speed of adjustment is very slow to word equilibrium. The significance of this term ratifies the long run relationship between variables. According to equation (10) the coefficient of change in current capital stock is positively impacting on the economic growth as expected. The value of change in first lagged labor shows negative relationship with economic growth as explained in above model that labor force is not efficient. The magnitude of change in current transport oil consumption shows positive impact on economic growth in short run. If there is one percent change in the current transport oil consumption there will be $0.16 \%$ change in the economic growth. In 1981 oil prices increases internationally, due to invasion of Afghanistan that's why lots of investment plans remained uncompleted and also due to Supply of oil from Iraq decline caused by Iran-Iraq war. In the start of 2005 the Nigeria economy was in its better condition due to increased growth of GDP in 2004, the oil prices were also stable in these years so it has positive impact on the economic growth of Nigeria comparatively very low impact, international oil shock in 2005 has not affected the Nigeria economy. But it has positive significant influence on the economic growth. It is concluded from above discussion of dynamic model, that transport oil consumption has positive impact on GDP in long run and short run. Oil price has negative relationship between GDP in long run but there is no impact on growth in short run. Shock dummies have significant positive impact on the growth except one has significant negative impact but these shocks have very minute impact on the Nigeria economic growth.

\subsection{Dynamic Analysis for Power Sector Oil Consumption and Growth}

\section{Cointegrating analysis:}

Applying the Johansen cointegration test on second model that includes power sector oil consumption in Nigeria. There is need to set the VAR first so the VAR model estimated five variables (LY, LP, LPWG, LL and LK) and two exogenous pulse dummies, these dummies has significant contribution in the VAR model, 1979 and 2008 dummies has explained already in above discussion. Lag length tests has been used to identify the optimal lag. The results are given in the Table 4. As it we can examine through the Table 4, LR, FPE, SC and HQ criteria indicates the two lags for estimating the VAR at 5\%. When the significant lag is selected the VAR model estimated with two lags. In the model we also include the unrestricted trend and intercept in the model. Trends in the data but have no trends in cointegration regression. As discussed in the Johansen, Johansen and Juselius five different choices of intercept and trend (Table 4). Cointegrating relationship was examined between the variables, through the two test statistics, Trace test and Maximum Eigenvalue test proposed by the Maximum Likelihood Method of Johansen. These results are given in the Table 5. According to the Trace test statistics the null hypotheses $\mathrm{r}=0$ and $\mathrm{r} \leq 1$ is rejected at $5 \%$ against alternative hypotheses $\mathrm{r}$ $\geq 1$ and $r \leq 2$. Through the Maximum Eigenvalue test statistics the null hypotheses $r=0$ and $r \leq 1$ is rejected at $5 \%$ against the alternative hypotheses $r=1$ and $r=2$. Both test statistics indicates two cointegrating vector or there are two log run cointegrating relationships in the variables. But in this study we take only one cointegrating vector for further analysis (Table 5). Now the long run relationship has been examined through Johansen Maximum Likelihood Method. From here we can move forward to take cointegrating estimates and short run dynamics analysis of our model that is given below in equation 11. (Chi square values are in parenthesis).

Table 4. VAR Lag Order Selection for PWG and Growth.

\begin{tabular}{lllllll}
\hline Lag & Log L & LR & FPE & AIC & SC & HQ \\
\hline 0 & 257.7832 & NA & $3.31 \mathrm{E}-12$ & -12.25175 & -11.17439 & -11.86843 \\
1 & 484.9878 & 334.8278 & $8.36 \mathrm{E}-17$ & -22.8941 & $-20.73938^{*}$ & -22.12746 \\
2 & 517.3863 & $39.21921^{*}$ & $6.67 \mathrm{e}-17^{*}$ & $-23.28349 *$ & -20.05141 & $-22.13354^{*}$ \\
\hline
\end{tabular}

*indicates significant lag at $5 \%$ level. 
Table 5. Trace and Max Eigenvalue Test of Cointegration for PWG and Growth.

\begin{tabular}{lllll}
\hline Hypothesis & & & Test statistics & $\begin{array}{l}\text { Critical } \\
\text { values }\end{array}$ \\
\hline & Ho & Ha & & $\mathbf{5 \%}$ \\
\hline & $\mathrm{r}=0$ & $\mathrm{r} \geq 1$ & $110.3783^{*}$ & 69.81889 \\
$(\lambda$ trace $)$ & $\mathrm{r} \leq 1$ & $\mathrm{r} \geq 2$ & $59.87456^{*}$ & 47.85613 \\
& $\mathrm{r} \leq 2$ & $\mathrm{r} \geq 3$ & 26.57852 & 29.79707 \\
& $\mathrm{r} \leq 3$ & $\mathrm{r} \geq 4$ & 6.688208 & 15.49471 \\
& $\mathrm{r} \leq 4 \mathrm{r}$ & $\mathrm{r} \geq 5$ & 0.254841 & 3.841466 \\
& $\mathrm{r}=0$ & $\mathrm{r}=1$ & $50.50379^{*}$ & 33.87687 \\
$(\lambda \max )$ & $\mathrm{r} \leq 1$ & $\mathrm{r}=2$ & $33.29604^{*}$ & 27.58434 \\
& $\mathrm{r} \leq 2$ & $\mathrm{r}=3$ & 19.89031 & 21.13162 \\
& $\mathrm{r} \leq 3$ & $\mathrm{r}=4$ & 6.433367 & 14.26460 \\
& $\mathrm{r} \leq 4$ & $\mathrm{r}=5$ & 0.254841 & 3.841466 \\
\hline
\end{tabular}

*indicates significant at $5 \%$

$$
L Y_{t}=\frac{-2.10 \mathrm{LL}_{\mathrm{t}}}{(19.44)}-\frac{1.62 \mathrm{LP}}{(36.48)}+\begin{gathered}
0.22 \mathrm{LPWG}_{\mathrm{t}} \\
(27.14)
\end{gathered}+\begin{gathered}
2.25 \mathrm{LK}_{\mathrm{t}} \\
(74.47)
\end{gathered}
$$

In long run equation (11) for power sector oil consumption and growth the capital stock shows significant positive impact on the GDP of Nigeria as expected but labor force shows negative relationship with GDP because in Nigeria labor force is not so efficient nor productive to impact GDP positively. The coefficient of oil prices has significant negative influence on the GDP. If there is one percent increase in the oil prices there will be $1.62 \%$ decrease in the GDP. The reason of negative relationship has explained above in detail. We can say that increase in the oil prices in the energy sector cause increase in the electric bills, petrol prices, increase the tax and also increase in the circular debt, which has throws bad impact on economic growth. The coefficient of power generation oil consumption shows positive impact on the GDP. If there is one percent increase in the power sector oil consumption there will be $0.22 \%$ increase in the GDP. So oil consumption in this sector is important determinant to influence the economic growth positively in long run. Short run dynamics results: Short run dynamic model given in equation (12) for power sector oil consumption and growth is evaluated through the general to specific approach estimated with two lags selected on the basis of diagnostic tests. (t-statistics are in parenthesis).

$$
\begin{aligned}
& \Delta \mathrm{LY}_{\mathrm{t}}=\begin{array}{c}
0.08 \\
(4.92)
\end{array}-\begin{array}{c}
0.001_{\mathrm{t}} \\
(-8.41)
\end{array}-\begin{array}{c}
0.23 \Delta \mathrm{LY}_{\mathrm{t}-1} \\
(-2.16)
\end{array}+\begin{array}{c}
0.13 \Delta \mathrm{LK}_{\mathrm{t}-2} \\
(4.18)
\end{array}-\begin{array}{c}
0.28 \Delta \mathrm{LL} \\
(-4.01)
\end{array}-\begin{array}{c}
0.22 \Delta \mathrm{LL}_{\mathrm{t}-1} \\
(-2.53)
\end{array}+\begin{array}{c}
0.01 \Delta \mathrm{L} \mathrm{PWGt} \\
(4.05)
\end{array}-\begin{array}{c}
0.01 \Delta \mathrm{LPWG}_{\mathrm{t}-2} \\
(-4.62)
\end{array}+
\end{aligned}
$$

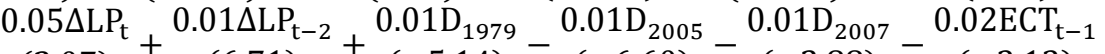

$$
\begin{aligned}
& (2.07)+(6.71)+(-5.14)-(-6.60)-(-2.88)-(-3.13)
\end{aligned}
$$

Diagnostic tests

$\mathrm{R}^{2}=0.95$, Adjusted $\mathrm{R}^{2}=0.89$

Breusch Godfrey LM test of Autocorrelation $\mathrm{F}_{(1,15)}=$ $0.81(0.38)$, Jarque Bera test of Normality $\chi_{(2)}=5.43(0.06)$,

Breusch Pagan Godfrey Hetroscadasticity Test $\mathrm{F}_{(20,16)}=$ 0.78(0.70), Diagnostic tests of dynamic model (12) are demonstrated here, first by examining the serial correlation through LM test. The value of F statistics is 0.81 so we cannot reject the null hypotheses of no serial correlation. The chi square $\chi 2$ amount of Jarque Bera is 5.43 tells that residual follow the normal distribution as we cannot reject the null of hypothesis and also the residual have equal spread of variance by observing the $F$ statistics of hetroscadasticity test that is 0.78 . The $\mathrm{R}^{2}$ and adjusted shows that independent variables are explained $95 \%$ and $89 \%$ by dependent variable respectively. Now the model is well specified for explanation of dynamic relationship. The value of $\mathrm{ECM}_{\mathrm{t}-1}$ is negative and significant to theory. The value in equation (12) indicates the error is correcting with the speed of $0.02 \%$ in the one year. The significance of this term also approves the long run relationship between variables. The coefficient of change in current capital stock in equation (12) is positively influence on the economic growth as expected. The value of change in current and first lagged labor shows negative relationship with growth as explained in above model that labor force is not efficient. The magnitude of change in current power sector oil consumption shows positive impact on growth in short run. If there is one percent change in the power sector oil consumption there will be $0.01 \%$ change in the GDP. But the change in lagged value of power sector oil consumption shows negative relationship with growth. It could be the reason of energy is treated as intermediate good in the previous year. The negative impact could be the alternative use of energy product like cheaper gas consumption. If there is one percent change in the current and lagged oil price there will be 0.05 and $0.01 \%$ change in the growth. According to Rasmussen and Roitman, 125 importing countries including Nigeria shows positive impact of oil prices on the GDP. If there is one percent increase in the change of current and lagged oil pr ice there will be 0.10 and 0.13 percent increase in the economic growth. So increase in the prices some time takes as good time in the economy, as increase in oil prices generally appears to be demand driven. Also study of Akram shows positive significant relation between oil price increase and growth in case of Nigeria. Dummy has positive impact on the growth of Nigeria however in 1979 there was second big oil shock in world. Dummy 2005 added due to increase of oil prices internationally due to destruction of Hurricane Katrina and decline in Iraq's oil supply and the great earth quack has badly impacted on all sectors of the economy and in 2007 the global financial crisis cause to increase in oil prices that have negative influence on the growth of Nigeria. So finally it can be said that, power sector oil consumption effect GDP positively in long run and also in short run. Oil price has negative relationship with GDP in long run and positive in short run. Oil Shock dummies variables also have significant impact on Nigeria economic growth. 


\subsection{Dynamic Analysis for Industrial Oil Consumption and Growth}

\section{Cointegrating analysis:}

Applying the Johansen cointegration test on third model that includes industrial oil consumption in Nigeria. There is need to set the VAR first so the VAR model estimated with five variables (LY, LP, LIND, LL and LK) and two exogenous pulse dummies. Dummy is added that have significant exogenous impact in the given VAR system, increase in oil prices up to $\$ 40$ in last quarter of 2004 and reaches at $\$ 50$ per barrel in 2005 due to the destruction of hurricane Katrina and decline in the supply of Iraq's oil production. As Iraq contain large oil reserve. Dummy capturing the effect of second oil prices shock that led from 1979 to 1981 , in 1981 there was decline in the oil supply from middle east and oil glut of 1981 due to decrease in oil consumption due to its high price. Lag length selection criteria such as; Log L, LR, FEP, AIC, SC, HQ has been used to select the optimal lag. The results are given below in the Table 6. We can see that, According to the Table 6 LR, FPE and AIC criteria indicates the two lags for estimating the VAR at $5 \%$. When the significant lag is selected the VAR model has estimated with two lags (Table 6). In the model we also include the unrestricted trend and intercept in the model same as previous model. Trends in the data but have no trends in cointegration regression. As discussed in the Johansen and Johansen and Juselius five different choices of intercept and trend. Cointegrating relationship has examined the two test statistics, Trace test and Maximum Eigenvalue test calculated.

Table 6. VAR Lag Order Selection for IND and Growth

\begin{tabular}{lllllll}
\hline Lag & Log $\mathbf{L}$ & LR & FPE & AIC & SC \\
\hline 0 & 267.9786 & NA & $1.14 \mathrm{E}-12$ & -13.3146 & -12.66825 \\
1 & 501.6226 & 368.9116 & $1.99 \mathrm{E}-17$ & 24.29593 & $-22.57215^{*}$ & $-23.68262^{*}$ \\
2 & 532.2705 & $0.32621^{*}$ & $1.66 \mathrm{e}-17 *$ & $24.59319^{*}$ & -21.79205 \\
\hline
\end{tabular}

*indicates significant lag at 5\% level.

Table 7. Trace and Max Eigenvalue Test of Cointegration for IND and Growth.

\begin{tabular}{lllll}
\hline Hypothesis & & & Test statistics & Critical values \\
\hline & $\mathrm{r}=0$ & $\mathrm{r} \geq 1$ & $103.7253^{*}$ & 69.81889 \\
& $\mathrm{r} \leq 1$ & $\mathrm{r} \geq 2$ & $52.30240^{*}$ & 47.85613 \\
$(\lambda$ trace $)$ & $\mathrm{r} \leq 2$ & $\mathrm{r} \geq 3$ & 17.70686 & 29.79707 \\
& $\mathrm{r} \leq 3$ & $\mathrm{r} \geq 4$ & 7.306180 & 15.49471 \\
& $\mathrm{r} \leq 4$ & $\mathrm{r} \geq 5$ & 1.392491 & 3.841466 \\
& $\mathrm{r}=0$ & $\mathrm{r}=1$ & $51.42288^{*}$ & 33.87687 \\
& $\mathrm{r} \leq 1$ & $\mathrm{r}=2$ & $34.59554^{*}$ & 27.58434 \\
$(\lambda \max )$ & $\mathrm{r} \leq 2$ & $\mathrm{r}=3$ & 10.40068 & 21.13162 \\
& $\mathrm{r} \leq 3$ & $\mathrm{r}=4$ & 5.913689 & 14.26460 \\
& $0 \mathrm{r} \leq 4$ & $\mathrm{r}=5$ & 1.392491 & 3.841466 \\
\hline
\end{tabular}

*indicates significant at $5 \%$

The Maximum Likelihood Method by Johansen. These results are given in the Table 7 . According to the Trace test statistics the null hypotheses $r=0$ and $r \leq 1$ is rejected at $5 \%$ against alternative hypotheses $r \geq 1$ and $r \leq 2$. Through the Maximum Eigenvalue test statistics the null hypotheses $r=0$ and $r \leq 1$ is rejected at $5 \%$ against the alternative hypotheses $\mathrm{r}=1$ and $\mathrm{r}=2$. Both test statistics indicates two cointegrating vector or there are two long run cointegrating relationships in the variables for this model. But in this study we take only one cointegrating vector for further analysis (Table 7). Now will estimate the of long run coefficients of power sector and growth model by using Maximum Likelihood Method (Chi square values are in parenthesis)

$$
\mathrm{LY}_{\mathrm{t}}=\begin{gathered}
0.20 \mathrm{LIND}_{t} \\
(9.42)
\end{gathered}+\begin{gathered}
5.83 \mathrm{LL}_{t} \\
(102.01)
\end{gathered}-\begin{gathered}
2.46 \mathrm{LP}_{t} \\
(62.56)
\end{gathered}-\begin{gathered}
1.16 \mathrm{LK}_{t} \\
(18.31)
\end{gathered}
$$

The normalized long run equation (13) given above whose estimates are given by adding the sectoral oil consumption of industrial sector. The labor force variables shows significant positive impact on the GDP as expected. The capital stock shows negative impact on GDP, if here is one percent increase in the capital stock there will be $1.16 \%$ decrease in the GDP. Negative relationship is due to inefficient investment in different sectors of economy also due to shortage of capital stock to influence positively on GDP. The oil price shows negative relationship with GDP. As explained above in the model. Higher oil prices have bad impact on the economy due to its cost. The industrial oil consumption indicated positive long run relationship with GDP. The positive relationship has explained above, such as oil consumption in industrial sector for different needs enhance the growth of the industry and overall economy. We know oil is becoming basic need in production sector. So if there is $1 \%$ increase in industrial oil consumption there will be $0.20 \%$ increase in the GDP. Short run dynamic results: Now the Error Correction Model has estimated for industrial oil consumption and growth, it is estimated through general to specific approach at second lag selected on the basis of diagnostic tests illustrated below equation (14). (T-statistics are given in parenthesis).

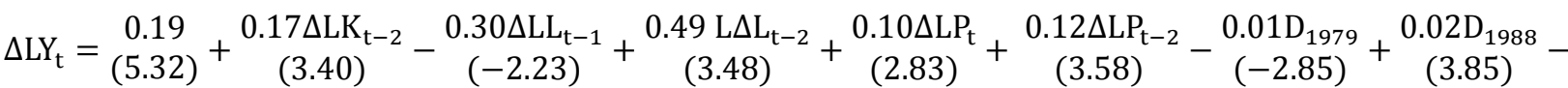

$$
\begin{aligned}
& 0.04 \mathrm{D}_{2008}-0.01 \mathrm{D}_{2005}-0.01 \mathrm{ECT}_{\mathrm{t}-1} \\
& (-5.00)-(-3.13)-(-4.96)
\end{aligned}
$$

Diagnostic tests:

$\mathrm{R}^{2}=0.73$ Adjusted $\mathrm{R}^{2}=0.62$
Breusch Godfrey LM test of Autocorrelation $\mathrm{F}_{(1,24)}=$ $0.02(0.88)$, Jarque Bera test of Normality $\chi 2(2)=0.69(0.70)$, 
Breusch Pagan Godfrey Hetroscadasticity Test $\mathrm{F}_{(11,25)}=$ 0.62(0.78),

Diagnostics of third dynamic model (14) are described here, mainly by checking the serial correlation through LM test. The value of F statistics is 0.02 so we cannot reject the null hypotheses of no serial correlation. The chi square $\chi^{2}$ value of Jarque Bera is 0.62 tells that residual follow the normal distribut ion as we can cot reject the null of hypothesis and also the residual have equal spread of variance by examining the F statistics through BreuschPagan Godfrey test of hetroscadasticity that is 0.62 . The $\mathrm{R}^{2}$ and adjusted $\mathrm{R}^{2}$ shows that independent variables are explained $73 \%$ and $62 \%$ by dependent variable respectively. Now, we move forward for description of dynamic relationship. The magnitude of $\mathrm{ECM}_{\mathrm{t}-1}$ is negative and significant according to theory given in equation (14). The value shows the error is correcting with the speed of $0.01 \%$ in the one year. We can see that the speed of adjustment is very slow to equilibrium. The significance of this term confirms the long run relationship between variables. The coefficient of change in lagged capital stock is positively impacting on the economic growth as expected and explained in the first dynamic model. The value of change in first lagged labor shows positive relationship with economic growth as it's according to theory because labor force helps to increase the growth but second lag shows negative impact as explained in previous dynamic equation. The magnitude of change in oil prices in current and lagged period shows positive impact on economic growth in short run. If there is one percent change in the current and lagged oil price there will be 0.10 and 0.12 percent change in the economic growth respectively. The effect of dummies have already described above. From the dynamic analysis between industrial oil consumption and growth it is summaries that, there is positive relationship between industrial oil consumption and GDP in long run but IND oil consumption has not influencing in short run to growth. Oil prices negatively related with GDP in long run and positively in short run. Oil shock dummies impacting negatively except one, but these have very less influence on the growth of Nigeria.

\section{Conclusion}

Nigeria face oil related problems since many years, specifically oil prices and its increasing demand in every sector of economy. From this point of view of this study, Nexus of oil price and shocks on economic growth has been study to include sectorial oil consumption. Time series approach is used in the study to test the long run and short run dynamics through Johansen approach of co integration firstly ADF test for finding order of integration I (d). Annual date of 1970-2016 is use for analysis. Three models of CobbDouglas production function are constructed for three major oil sectors including oil prices depending on GDP. Shocks dummies are also included in these models as previous studies did not include the oil shocks in data. In Nigeria few paper are found on disaggregated oil consumption and GDP, in past studies sectoral consumption of oil, oil price and shocks ignored specifically Nigerian's oil prices were not taken into consideration in any paper for this context, So oil price variable and shock dummies have been added in the analysis. From the analysis finding it can be concluded that oil consumption variables have positive impact on economy in long run and also shows the long run causal relationship from oil consumption variables to GDP also oil price variable shows negative impact as expected. In short run oil consumption variables shows very little impact on economic growth of Nigeria however, shocks dummies also influencing negatively on growth in short run but with low rate. In short run consumption as well oil price variables also show causal relation toward growth. So we can say oil consumption is important to enhance the economic growth of Nigeria specifically in long run but less contribution toward economic growth in short run.

The previous study of Ogundipe and Apata in Nigeria investigated the relationship between energy consumption and economic growth is compare to the results of present study, it is seen that by estimating individual dynamic model for each sector it give different results. In previous study oil price variable and shock dummies were not included which have significant impact on the economy. Energy consumption variables are positively cointegrated with economic growth as concluded in previous study. Results of this study also supports the results of the study of Onakoya which shows positive significant relationship of increase in oil prices for Nigeria. The results are also consistent with the findings of Aminu and Aminu that capital and labor variables have greater impact on economic growth then other variables.

\section{Recommendations}

The policy implications for this study are, firstly; Government should invest on the workforce and capital, as these variables shows greater impact on economic growth of Nigeria both in long run and short run. Secondly, the transport sector oil consumption that is higher in oil consumption of Nigeria has larger impact on economy, there is need to improve controls on oil prices so as to reduce impacting negatively in the long run on other sector. As high transport cost begin about inflation. Finally, Industrial and power oil consumption are very important part of any economy that could boost up growth but these sectors need much planning in prices controlling and developing to safe guards it from oil shocks, so that these sector could take part in up grating the economy of Nigeria.

\section{References}

[1] Abid M, Sabri M (2012) Energy Concept-Economic Growth Nexus: Does the Level of Aggregation Matter? International Journal of Energy Economic and Policy 2: 55-62. 
[2] Adeyemi A. Ogundipe and Ayomide Apata (2013) Electricity Consumption and Economic Growth in Nigeria. Journal of Business Management and Applied Economics Vol. II, Issue 4 July 2013.

[3] Aigbedion, I., \& Iyayi, S. E. (2007). Diversifying Nigeria's Petroleum Industry. International Journal of Physical Sciences, 2, 263-270.

[4] Akarca AT, Long TV (1980) On the Relationship between Energy and GNP: A Reexamination. Journal of Energy Development 5: 326-331.

[5] Aminu M. Mustapha and Aminu M. Fagge (2015) Energy Consumption and Economic Growth in Nigeria: A Causality Analysis. Journal of Economics and Sustainable Development Vol.6, No.13, 2015.

[6] Bright Orhewere and Machame Henry (2011) Energy Consumption and Economic Growth in Nigeria. JORIND (9) 1, June, 2011. ISSN 1596.

[7] Cobb C, Douglas P (1928) A Theory of Production. An American Economic review 18:139-165.

[8] Dickey DA, Fuller WA (1979) Distribution of Estimators for Autoregressive Time Series Regression with a Unit Root. Journal of the American Statistical Association 74: 427-431.

[9] Engle RF, Granger CWJ (1987) Co-integration and Error Correction: Representation, Estimation, and Testing. Econometrica 55: 251-276.

[10] Georgescu-Roegen N (1975) Energy and Economic Myths. Southern Economic Journal 41:347-81.

[11] Hamilton J. D (2011) Historical Oil Shocks. NBER Working paper No. 16790.

[12] ekwe, I. Assessing the Future of Nigeria's Economy: Ignored Threats from the Global Climate Change Debacle. Africa Economic http://www.afbis.com/analysis/climate_change.htm

[13] Johansen S (1988) Statistical Analysis of Cointegrating Vectors. Journal of Economic Dynamics and Control 12: 231254.

[14] Johansen S (1995) Likelihood Based Inference in Cointegrated Vector Autoregressive Models. Oxford: Oxford University Press.

[15] Johansen S, Juselius K (1990) Maximum Likelihood Estimation and Inference on Co - integration with Applications to the Demand for Money. Oxford Bulletin of
Economics and statistics 52: 169-210.

[16] Kraft J, Kraft A (1978) On the Relationship between Energy and GNP. Journal of Energy and Development 3: 401-403.

[17] Lee C, Chang C (2005) Structural Breaks, Energy Consumption, and Economic Growth Revisited: Evidence from Taiwan. Energy Economics 27: 857-872.

[18] Levent K (2007) Testing Causal Relationship between Energy Consumption, Real Income and Prices: Evidence from Turkey. MPRA Paper 1: 1-29.

[19] MacKinnon JG (1991) Critical Values for Cointegration Tests. In: Engle RF and Granger J, Long-run (eds), Economic Relationships: Readings in Cointegration. Oxford University Press.

[20] Michael Chugozie Anyaehie and Anthony Chukwudi Areji (2015) Economic Diversification for Sustainable Development in Nigeria Open Journal of Political Science, 2015, 5, 87-94 Published Online March 2015 in SciRes.

[21] Nazir S, and Hameed T (2015) Impact of Oil Price and Shocks on Economic Growth of Pakistan: Multivariate Analysis (Sectoral Oil Consumption). Bus Eco $J$ 6: 182. doi:10.4172/2151-6219.1000182

[22] Rasmussen NR, Roitman A (2011) Oil Shocks in a Global Perspective: Are They Really That Bad? IMF.

[23] Sanusi, L. S. (2010). Growth Prospects for the Nigerian Economy. Convocation Lecture Delivered at the Igbinedion University Eighth Convocation Ceremony, Okada.

[24] Soytas U, Sari R (2003) Energy Consumption and GDP: Causality Relationship in G-7 Countries and Emerging Markets. Energy Economics 25: 33-37.

[25] Sustainable Development Definition (1993). An Architect's Guide to Designing for Sustainability.

[26] Towards Sustainable Development. Our Common Future. Report of the World Commission on Environment and Development, UN Documents: Gathering a Body of Global Agreements, the NGO Committee on Education of the Conference of $N G O s$.

[27] Zaman B, Farooq M, Ullah S (2011) Sectoral Oil Consumption and Economic Growth in Nigeria: An ECM Approach. American Journal of Scientific and Industrial Research 2: 149-159. 